\title{
Mit navn er Brown, fang mig hvis du kan
}

\section{Personkonstruktioner i Michael Cunninghams}

\section{The Hours}

Michael Cunningham fik Pulitzerprisen for romanen The Hours i 1999.

I romanen er de centrale begivenheder en anden prisoverrækkelse, nemlig overrækkelsen af den lige så prestigiøse 'Carroutherspris' til bogens aidsramte forfatter Richard Brown og den fest, som Richards veninde og forlægger Clarissa Vaughan, i den anledning holder for ham. Romanen er på denne måde tæt på sin egen forfatters virkelighed (selv om det givetvis ikke er nok at plante en pris hos sin hovedperson for selv at få en). Vi er i et 90 ’er New York, i en forlags- og medieverden med dens sammenrend af mondæne stjerner, hippe wannabees og forskellige seksuelle orienteringer. Vi følger Clarissa i forberedelserne til aftenens selskab. »Der mangler stadig at blive købt blomster« er indgangsreplikken til det første kapitel om Clarissa Vaughan, der blandt venner går under navnet 'Mrs. Dalloway'.

Hermed er vi samtidig også langt fra Michael Cunninghams eget liv, i hvert fald i ydre historisk forstand og tæt på litteraturens liv, tæt på den litterære intertekst, som Cunningham væver ind og ud af sin roman, nemlig Virginia Woolfs berømte roman Mrs. Dalloway fra 1925, som Woolf i øvrigt i en lang periode, mens hun skrev på den, kaldte netop The Hours. Cunningham tager i sin bog stof og figurer fra Woolf og omsætter dem i sin egen litterære konfiguration. Man kan sige, at han stjæler med arme og ben og uden blusel, helt op i titel og overskrifter, og man kan begynde at tænke på ophavsrettigheder. Men man kan også sige, at han giver Mrs. Dalloway et nyt efterliv i sit værk, at han forlænger dens virkning i en senere tidsalder, og at hans moderne gennemskrivning af stoffet fra Mrs. Dalloway er en hyldest til Virginia Woolf.

Begge dele smager måske en smule af markedsrigtighed, og risikoen ved Cunninghams projekt er da også, at ideen tager overhånd, at bogen bliver en satsning på en litterær konjunktur, hvor stikordene er 'intertekstualitet' og 
'metafiktion', altså dette at en tekst skriver sin betydning i dialog og spil med andre tekster, som den inkorporerer og gør til sit henvisningsmateriale. At den mao. gør sig som en dygtig og veloplagt udførelse af en idé, der appellerer til tidens litterære smag. Jeg har selv under min læsning ikke helt kunnet afvise sådan en fornemmelse. Men der er andre ting i romanen, der samler interessen og vinder over den bekymring.

\section{Personerne}

Bogen fortæller i tre tidsspor om tre forskellige kvinder, som vi følger i deres tanker og gøremål gennem en enkelt dag. Vi følger Clarissa, kaldet Mrs. Dalloway, en junidag i New York ca. 1998, vi følger Virginia Woolf på en anden junidag i Richmond uden for London i 1920'erne i den periode, hvor hun skriver på manuskriptet til The Hours, og vi følger en tredje kvinde, Laura Brown, en ung husmor i Los Angeles i slutningen af 40'erne, som venter sit barn nr. to, og som just denne junidag er begyndt at læse Woolfs roman Mrs. Dalloway. Dette er set uppet. Vi har altså: forfatteren Woolf, vi har: laeseren af Woolf, og vi har: hovedpersonen Clarissa, der er den moderne replik af Woolfs Mrs. Dalloway. Fælles for de tre kvinder er i øvrigt, at de venter gæster og træffer forberedelser til deres selskab, mens vi følger dem, akkurat som Clarissa Dalloway i den 'rigtige' roman af Woolf. - Dette er som sagt arrangementet, det handlingsskema, der er kalkeret efter Woolfs Dallowaybog, eller de spilleregler, Cunningham giver sig selv at komponere bogen efter. Reglerne peger på fiktionsspillet, spillet på teksten i teksten, Mrs. Dalloway bag The Hours. Men udførelsen peger også på en virkelighed bag teksten, al den stund episoderne i Virginia Woolf afsnittet er bygget over dokumentarisk stof fra Woolfs liv og fra hendes dagbøger. Man kan sige, og det vil være et hovedspor i det følgende, at Cunningham igennem fiktionen søger ud over teksten, eller at han åbner teksten ud mod både forfatterens og læserens verdener. Woolf er forfatteren, der er optaget af sin skriveproces, men hun er samtidig også hovedperson i sit liv i Richmond i de 'timer' Cunningham fortæller om. Og læseren, Laura Brown er ligeledes også hovedperson i sin egen historie, som Cunningham krydsklipper med de to andres.

Således bliver en ledetråd i Cunninghams roman, eller måske ligefrem dens generative dynamik: forholdet mellem personer og fortælling, hvilket også tager sig ud som forskellige spændingsgrader mellem fiktion og virkelighedsstof. Romanen lader sig læse som en intens gennemprøvning af spørgsmålet om hvad en litterær person er, hvordan den litterære person opbygges, hvilken funktion karakteren har i det fortalte plot og i forholdet til 
de andre personer. Og ikke mindst hvad det er for identifikationer, der med romanpersonen udspændes imellem tekst og læser.

Cunningham lader sine personer udfolde sig i situationsspil, Virginia i samspil med ægtemanden Leonard og søsteren Vanessa; Clarissa i samspil med vennerne Richard, Sally, Louis og datteren Julia; Laura i samspil først og fremmest med sønnen Richie, og dernæst med manden Dan og naboveninden Kitty. Samtidig får de også hver især kontur i krydsklipningen af deres individuelle historier, Virginias med Clarissas, Clarissas kontra Lauras, og vice versa, der kastes ekko og kontrastvirkninger mellem de tre kvinder, dels via referencen til Mrs. Dalloway, der er en klangbund hele vejen, og dels også ved det relief, den skiftende samfundshistorie sætter dem i.

Men alt dette lyder måske stadig lovlig skematisk, for planlagt og gennemtænkt, som om romanens personer og scener ikke bliver sluppet løs med deres egen energi og på egne betingelser. Men der er hele tiden begge dele i romanen The Hours, der er konstruktionen, det, der viser, at personerne er præformerede konstrukter, tangenter fortælleren spiller på, og så en anden dybere understrøm, som animerer det hele, og som har at gøre med de eksistentielle temaer, som personerne er indbyrdes forbundne i, og som får stemme i fortællingens sproglige lag.

Man kan sige, at Cunningham bryder sit eget skema fra starten. Bogens første situationsbillede bryder ud af rækken, det er nemlig en skitse af den ældre Virginia Woolf, den dag i 1941, hvor hun, plaget, dybt ensom og determineret, opgiver at leve videre. Vi følger hende på vej ned til floden, hvor hun drukner sig, og følger hende videre, flydende med strømmen, og registrerer gennem hendes synsvinkel, den druknedes, den forbiglidende verden over vandspejlet, den verden af organisk skønhed, verdenskrig og dagligdags tilfældigheder, der lever videre - som en art forlængelse af hendes afsluttede liv. - Dette spring i kronologien, springet frem mod slutningen, før historien er begyndt, er begyndelsen, er det grundtema, der som et musikalsk tema arbejder sig videre i forskellige transponeringer og opløsninger i kontratemaer i resten af bogen. Døden, selvmordet, er den absolutte grænse, op mod hvilken 'timerne' får deres betydning, den grund hvorpå betydning formes for Cunninghams spand af personer. $\mathrm{Og}$ det er i de enkelte personers gennemspilning af dette tema, at de også bryder ud af det skematisk præfigurerede, at de 'vokser ud mod læseren', samtidig med at partituret, bogens kompositionsregler holdes fast. Livet, døden og seksualiteten er de uendeligt variable og kombinerbare størrelser. Så enkelt er Cunninghams budskab på en måde. $\mathrm{Og}$ personerne ses som forskelligt sammensatte måder at rumme, forstå og komme om ved dette almene vilkår på. 


\section{Mrs. Brown}

'Mrs. Brown', som Cunningham kalder sin amerikanske husmor-læser er som taget ud af den ørkesløse almindelighed i en anonym $40^{\prime}$ er forstad til Los Angeles. Efterkrigsamerika, nabokonen, der kommer på besøg og sludrer over en kop formiddagskaffe. Laura der bager fødselsdagskage sammen med lille Richie til festmiddagen for faderen, der er vendt hjem fra verdenskrigen med udmærkelse. Hverdagens Americana set og forstørret op gennem hovedpersonen Lauras perspektiv. Men man føler, at Cunningham har noget på spil med denne banale figur, at Laura ud over at spille rollen som romanlæser også er den person, der er drevet længst ud mod et eksistentielt virkelighedsplan i romanen. Hun er også den af romanens personer, der bevæger sig mest ubundet af romanens forlæg, Dalloway-teksten, selv om det vil vise sig ved nærmere undersøgelse, at også hun har sin intertekst, og at Cunningham også fører hende i et usynligt snoretræk.

Cunningham har nemlig hugget figuren 'Mrs. Brown' fra et kendt essay af Virginia Woolf (fra 1922) med titlen »Mr. Bennett and Mrs. Brown«, hvor Woolf fører en central diskussion om netop: karakterens/hovedpersonens betydning i moderne fiktion. Jeg kan ikke gøre retfærdigt rede for essayet i dets helhed, men det afgørende her er også, hvad det er for en betydning Woolf tilskriver karakteren.

Det forklarer hun meget direkte:

"Jeg tror at alle romaner [...] har at gøre med karakterfremstilling, og at det er for at udtrykke karakterer - ikke for at prædike doktriner, synge sange eller fejre det Britiske Imperiums glorværdighed, at romanformen har udviklet sig så kluntet, ordrigt og udramatisk, så rigt, elastisk og levende«. ${ }^{1}$

Woolf bruger også essayet til at vise, hvor svært det er at 'udtrykke karakterer' i den moderne roman, og hvordan 20'ernes unge forfattere, Forster, Lawrence, Joyce og hun selv, er intenst optaget af at danne et helt andet begreb om 'den litterære karakter' end det overleverede, det som stammer fra det 19. århundredes realistiske litteratur, og som stadig er en norm og kanon, de moderne dømmes på. Essayets 'Mr. Bennett' er nemlig navnet på en af $20^{\prime}$ ernes forfattere og kritikere fra slægtleddet før Joyce, James og Woolf. Han var kendt for at være kritisk over for den nye litteratur, netop fordi den, som han mente, var »ude af stand til at skabe karakterer, der er vir-

1. „Mr. Bennett and Mrs. Brown«, her citeret fra Virginia Woolf: Collected Essays, Vol. I, London 1968, p. 324 . 
kelige, sande og overbevisende." Essayets anden titelfigur er så 'Mrs. Brown'. Det er Woolfs egen vision af en karakter. »[E]n lille figur rejste sig foran mig«, fortæller hun, da hun skulle i gang med at skrive sit essay, »en lille mandlig eller kvindelig figur, som sagde, »My name is Brown. Catch me if you can««. Mit navn er Brown, fang mig hvis du kan, - «un få fanger fantomet« tilføjer hun lidt efter, "de fleste må stille sig tilfreds med en raslen af hendes kjole eller et strejf af hendes hår«. ${ }^{2}$ Hertil fortæller Woolf en lille historie, som illustrerer hvordan en karakter bliver til i forfatterens hoved, eller hvordan vi alle konstant digter karakterer i vores omgang med hinanden og i flygtige møder med folk på vores vej. Woolf sidder i toget fra Richmond til Waterloo. I kupeen overhører hun brudstykker af en samtale mellem sine medpassagerer, en lille ældre kvinde og en lidt yngre mand, og hun giver sig uvilkårligt til at forestille sig denne kvindes forhold, hendes børn, hendes tidligere liv, hendes formål med turen til London, osv. Hun er blevet til Mrs. Brown i en fortælling, som nærer sig af det flygtige møde, en fantasifigur, som bærer alle muligheder i sig, som er 'livet selv', siger Woolf endda. Men Mrs. Brown kan netop ikke 'fanges' i den gamle Dickenske eller Bennettske karaktermodel, som registrerer udseende, bolig, penge-og familjeforhold, udenværker, ned til mindste detalje.

Woolf prøver så selv at indfange denne karakter:

»Hun sad i sit hørne overfor mig, meget proper, meget lille, nærmest sær og intenst lidende. Det indtryk hun gjorde, var overvældende. Det kom væltende som et vindstød, som en lugt af noget der brænder. Hvad var det sammensat af - dette overvældende og mærkværdige indtryk? Myriader af irrelevante og uforenelige forestillinger trænges i ens hovede ved sådan en lejlighed; man ser personen, man ser Mrs. Brown midt i alle mulige scener.... $\|^{3}$

Woolf fantaserer videre, men uden at komme frem til et resultat. Eller hendes pointe er, at der ikke er nogen sikker eller fastlagt opskrift på at fremstille den litterære person. »Jeg lod Mrs. Brown slippe gennem mine fingre«, indrømmer hun, »jeg har ikke fortalt Dem noget som helst om hende». - Den litterære person må med andre ord genopfindes sammen med den moderne romans poetik, - og man kan selvfølgelig, set i bakspejlet, tilføje, at det var det, Woolf gjorde, altså genopfandt den litterære person, netop i Mrs. Dalloway, som hun arbejdede på, mens hun skrev dette essay.

2. Loc. cit., p. 319.

3. Loc. cit., p. 323. 
Cunningham har gjort det. Han har fanget en af Mrs. Browns utallige temporære skikkelser og givet hende både fornavn, familje og sorger og glæder. Laura Browns banale og udramatiske forstadsliv er det han vil fange, ikke for at fryse det fast i en æstetisk gestus, sådan som Flaubert engang gjorde med Emma Bovarys banale liv, men for at trænge ind i dets kroge og få noget af det, der er gemt dér til at give slip og 'vælte frem som et vindstød'.

Cunningham skildrer Laura Brown og sine andre personer med en variant af den stream-of-consciousness teknik, som han og mange før ham har lært hos Woolf og hendes generation. Der er masser af umærkelige synsvinkelskift og style indirect libre, der gengiver Lauras tankestil og hendes indre diskussioner med sig selv:

"En side til, beslutter hun; bare én. Hun er ikke parat endnu; de opgaver der ligger foran hende (tage morgenkåben på, børste håret, gå ned i køkkenet) er stadig for vage, for flygtige. Hun vil give sig selv et minut mere her i sengen, før hun begynder på dagen. $\iota^{4}$

Og der er masser af det, der i synsvinkelanalysen er blevet kaldt psykoanalogier, dvs. steder hvor fortællerens metaforiske udtryk giver stemme til Lauras flygtige fornemmelser. ${ }^{5}$ F.eks. på det citerede sted, hvor Cunningham fortsætter:

»Hun bliver overvældet af en bølgende følelse, en havdønning, der opstår under hendes bryst og bærer hende oppe, blidt lader hende flyde som om hun var et havvæsen, der blev kastet tilbage fra sandet, hvor det var drevet $\mathrm{i}$ land - som om hun var blevet sendt tilbage fra en verden af knugende tyngdekraft til sine sande omgivelser, saltvandets sugen og svulmen, den vægtløse stråleglans. $\ll^{6}$

Fortællerens stemme og Lauras følelse smelter i passager som denne sammen i udviklingen af et indre billede. Og teknikken er velkendt fra Woolf, der netop på denne måde ynder at forstørre en mikroskopisk følelse eller sansning op i et lyrisk udtryk, der gør det flygtige jævnbyrdigt med eller vigtigere end de mere konkrete handlingselementer.

4. Michael Cunningham: The Hours (org. 1998), London 1999, p. 40. Dansk oversættelse: Timerne, Kbh. 1998, p. 34.

5. Begrebet stammer fra Dorrit Cohn: Transparent Minds, Princeton 1978, p. 37 ff.

6. The Hours p. 44, Timerne p. 34 . 


\section{Fra Woolf til 'nouveau roman'}

Diskussionen om karakteren, om den litterære person, har haft et underligt forløb i moderne litteraturteori, den er nærmest blevet forbigået eller rangeret ud på et sidespor. Den er blevet ført først og fremmest som en fagdiskussion mellem forfattere indbyrdes, og har i mindre grad været et emne for litteraturteoriens interesse, og da slet ikke for den litteraturteori, der, som den meste i dag, har sit udgangspunkt i fransk strukturalisme og i senere fransk-amerikansk poststrukturalisme.

Virginia Woolf søgte i 20'erne at føre karakteren ad nye veje, at fange andre aspekter af 'the spirit we live by', af 'life itself', som hun kaldte Mrs. Brown, og hun forsvarede de modernistiske forfatteres øksehug mod det udlevede persongalleri fra det 19. århundredes romaner medsamt alle dets rekvisitter. Verden og mennesket var i det 20 årh. blevet så forandret, at de ikke mere kunne skrives på de gamle formler. Der måtte ryddes ny grund i romanen: »og det er lyden af deres, [dvs. de moderne forfatteres] økser, vi hører - en stærk og stimulerende lyd i mine ører«, som hun skriver. Romanen Mrs. Dalloway var et laboratorium for hendes egne bestræbelser, og hun beskrev selv fuld af entusiasme i sin dagbog de opdagelser, hun gjorde under arbejdet med romanen. Et berømt sted, som Cunningham sætter som motto for sin roman, er notatet fra 30. August 1923:

»Jeg har ikke tid til at beskrive mine planer. Jeg burde sige en hel del om The Hours \& min opdagelse; om hvordan jeg udgraver smukke grotter bag mine personer; jeg tror det fremkalder nøjagtigt det jeg ønsker; menneskelighed, humor, dybde. Tanken er at grotterne skal hænge sammen, $\&$ for øjeblikket ser hver enkelt af dem dagens lys. $\ll^{7}$

Det omtalte rydningsarbejde, den modernistiske udrensning af de gamle karaktertyper, som Virginia Woolf og hendes gruppe indledte, har været en almen tendens i det 20. århundredes roman. Opgøret fik en iøjnefaldende fortsættelse hos 50'ernes litterære avantgarde, jeg tænker på de franske forfattere, som blev kendt under betegnelsen 'le nouveau roman'. Navnene er Alain Robbe-Grillet, Michel Butor, Claude Simon, Marguérite Duras og Nathalie Sarraute med flere. Uden at gå nærmere ind på alt det, der binder denne gruppe sammen og især ikke binder dem sammen, kan man i hvertfald sige, at gruppen førte opgøret med den litterære personlighed frem til dets radikale poetologiske konsekvens. I Robbe-Grillets poetik Pour un nou-

7. Citeret efter The Diary of Virginia Woolf, Vol. II; 1920-1924, London 1978. 
veau roman fra 1963 findes et kapitel med den nedgørende overskrift 'Om nogle forældede begreber', og det første point d'attaque er netop 'Le personnage':

»Vi har hørt tilstrækkeligt om den litterære karakter! (min ovs. af det franske 'personnage') Og det er tilsyneladende, desværre, ikke slut endnu. End ikke 50 års skranten og de mest seriøse skribenters mange gentagne konstateringer af dens død, har endnu formået at styrte den ned fra den piedestal, hvor den blev anbragt af det 19. århundrede. Den er nu et mumie, men troner stadig i samme majestæt - skønt falsk - i centrum af de værdier, den traditionelle kritik dyrker. Det er endog på den at kritikken kender sin 'rigtige' romanforfatter: »il crée des personnages $« \ldots . . \ll^{8}$

Robbe-Grillet henviser så til problematiseringen af karakteren i dén modernistiske litteratur, der udfylder mellemrummet mellem James- JoyceWoolf og nouveau roman. Romanerne skrives i jeg-form, eller personernes identitet flyder: Beckett udskifter navn og udseende på sin hovedperson i én og samme fortælling, Faulkner giver bevidst to personer samme navn i samme fortælling, og Kafkas K. i Slottet nøjes med et initial og har hverken ansigt, familje eller ejendom. Vi kunne supplere Robbe-Grillets liste med flere andre 'mænd uden egenskaber', og vi kan tilslutte os hans forklaring på fænomenet, når han peger på det sammenbrud, den individualistiske ideologi har lidt i det 20. århundrede:

"Verden er selv ikke længere denne private ejendom, dette arvegods eller denne vare, denne form for bytte, som det mere gjaldt om at erobre end at kende. Det at have et navn var utvivlsomt meget vigtigt i Balzacs borgerlige epoke. En karakter er vigtig, den er våbnet i den åbne konfrontation, den er håbet om succes og udøvelse af dominans. Det var noget at have et ansigt $\mathrm{i}$ et univers, hvor personligheden var middel og mål for al bestræbelse. «"

I det moderne perspektiv holder denne tro på 'menneskets almagt' imidlertid ikke. »Den eksklusive dyrkelse af 'mennesket' ", skriver Robbe-Grillet, "har gjort plads for en større og mindre antropocentrisk bevidsthed«. Romanen har tabt sin 'helt', men Robbe-Grillet profeterer også, at der dermed åbner sig nye horisonter og nye opdagelser at gøre for romanen.

8. Alain Robbe-Grillet: Pour un nouveau roman, Paris 1963, p. 31.

9. Op. cit. p. 33. 
Som sådan stiller Robbe-Grillet jo her samme diagnose på patient og sygdom som Virginia Woolf, underforstået den hensygnende 'personnage', men den fører til andre behandlingsforslag. Hos Robbe-Grillet selv, dvs. i hans romaner som f.eks. Les Gommes eller La Jalousie, er personerne, dvs. den traditionelle fortællings identificerbare skikkelser, udskiftet med anonyme synsvinkler eller med en flerhed af repeterende forløb, som opløser tid og rum og gør en antropomorficering af det fortalte vanskelig. Det menneskeligt tolkende centrum, der søger at besvare spørgsmålet om 'hvorfor' tingene er på denne bestemte måde, er erstattet med et kameraøje, der registrerer tingenes gådefulde 'hvordan'. Robbe-Grillet vil ikke udgrave smukke grotter, han vil ikke give personerne 'menneskelighed' og 'dybde', men granske strukturer og overflade.

Robbe-Grillet nærmer sig sin epokes, 60'ernes strukturalistiske litteraturteori. Hos den tidlige Barthes, Greimas, Bremond og Todorov var det de litterære teksters handlingsdynamik, der blev observeret, det var den narrative logik, der blev formaliseret i lingvistisk funderede logaritmer. Personerne i teksterne - nu forkorter jeg - blev reduceret til bærere eller funktioner af handlingen, og generaliseret i modaliteter og aktanter, dvs. strukturelle forhold på et dybere plan i teksten end dér, hvor vi som læsere ser dem udfolde sig og hører dem tale. Spørgsmålet om hvorvidt personerne var funktioner af handlingen eller omvendt, at handlingen måske kunne være en realisering af de i personerne iboende egenskaber og muligheder, sådanne spørgsmål blev overhovedet ikke stillet. Forestillingen om 'iboende egenskaber', hele personlighedssnakken, var netop et overstået kapitel og en sag, der var lukket for den nye litteraturvidenskab, der, på samme måde som Robbe-Grillet, bekæmpede forrige tiders illusioner om individet og dertil hørende falske forestillinger.

Formålet er ikke her at udrede hele 60'ernes litterære klima eller at gå i rette med dets tænkemåder. Når jeg prøver at retrospektivere noget af det, der foregår hos Cunningham, ud fra dette punkt, så er det fordi så godt som al nutidig tænkning over litteratur sætter af derfra, og fordi Cunningham heller ikke undgår at føre sin egen dialog med Woolf gennem dette tankefilter, direkte og indirekte. Og der er endnu et filter, der sætter dialogen mellem Woolf og Cunningham i et interessant perspektiv.

Nathalie Sarraute er Robbe-Grillets nouveau roman-kollega. I 1956 udgav hun nogle kritiske essays med titlen L'ère du soupçon, 'Mistankens epoke', som også handler om den moderne romans betingelser og netop om 'le personnage'. Hun refererer faktisk til Virginia Woolfs kritik fra 20'erne og til hendes pionerindsats med Mrs. Dalloway. Men Sarraute har også en reserva- 
tion over for Woolf, en reservation, som jeg i øvrigt ikke helt forstår nødvendigheden af. Det forekommer i hvertfald $m i g$, at det Sarraute selv gør i sine romaners 'sousconversations' er nedarvet i lige linje fra Woolf, dvs. Sarrautes raffinerede skildring af alle de mikroskopiske dramaer, der udspilles mellem linjerne og under den sproglige overflade i menneskers samkvem: stumme tilnærmelser, afslag, tilbagetrækninger, hævnakter, etc. Sarraute løsner ganske vist disse dramaer fra deres gamle ramme, fra 'le personnage' og fra karakterskildringen. Hendes metode består i at arbejde sig helt ned på et anonymt bevidsthedsplan, hvor tilstandene opfattes som 'partikler' og 'tropismer'. Læseren skal ikke kommes imøde med genkendelighed, siger hun, han skal tværtimod ud på det dybe, hvor der ikke er nogen bekvemme pejlemærker, som hjælper ham med at konstruere 'les pesonnages':

»Han er stedt og fastholdt hele vejen i en materie, der er anonym som blodet, i en magma uden navn, uden kontur. Hvis han kan orientere sig, så er det ved hjælp af de mønstre forfatteren lægger ud for ham. Ingen reminiscens fra hans fortrolige verden, intet konventionelt hensyn til sammenhæng og sandsynlighed skal forstyrre hans opmærksomhed eller bremse hans anstrengelse. $\|^{10}$

Her er det nok også, at Sarraute passerer Woolf og markerer det med et blik tilbage over skulderen. Woolf kunne endnu sige, at (jeg citerer Sarraute) »de modernes interesse ligger i psykologiens obskure områder", mens "psykologi' for Sarraute er en penibel term, ensbetydende med den humanistiske tro på individet og karakterportrættet, de faldgruber, som litteraturen netop er styret fri af. »Ordet »psykologi« er et af dem, som en forfatter i dag ikke kan høre anvendt på sig selv uden at slå øjnene ned og rødme«, skriver hun. ${ }^{11}$ Derfor graver hun sig ned $i$ et dybere og anonymere transpersonelt lag af den menneskelige erfaring og fremstiller dette i en art abstrakt prosa, som hun selv flere steder sammenligner med den nonfigurative udvikling i billedkunsten.

Så langt gik Woolf ikke, selv om hendes bøger og hendes sprog tog sig abstrakt nok ud for den læsende samtid, hendes roman Jacob's Room blev f.eks. rost, samtidig med at personerne blev kaldt spøgelser. Men Woolf ville ikke annullere karakteren, sådan som Sarraute og Robbe-Grillet eller strukturalisterne. Hun ville tværtimod genopfinde den på en ny grund, og hun ville komme sin læser imøde og definere en ny fælles basis i denne proces. Genkendelse og identifikation var og blev en kunstnerisk nøgle for Woolf, og

10. Nathalie Sarraute: L'ère du soupçon, Paris 1956, p. 91.

11. Op. cit. p. 99. 
deri ligger nok også den tydeligste forskel mellem hendes projekt og nouveau romans nulstilling af karakteren. Men jeg synes stadig at Sarraute underkender sin arv fra Woolf. - Hvorfor peger hun ikke på Woolfs underminering af den traditionelle karakter, hvorfor ser hun ikke hendes undergrundsarbejde med at forbinde alle de skjulte 'grotter' bag personerne i et transpersonelt fletværk? Woolf kaldte det selv 'tunnelarbejde'. For mig at se er Woolfs 'tunnelgange' og Sarrautes 'magma uden navn og kontur' blot forskellige navne på samme obskure område.

\section{Mellem Balzac og Woolf}

Laura Brown er utilpasset eller utilpas i sin tilværelse som amerikansk husmor. Vi hører det allerede i den første scene, hvor hun eskaperer fra sine morgenpligter og bliver liggende med romanen i sengen. Ambivalensen er skildret i den havmetafor, som jeg citerede, havdønningen med dens sugen og svulmen og vægtløse stråleglans, som bærer hende fra sandet tilbage i hendes sande element. Den slags billeder - for komplekse og navnløse tilstande - minder om Woolfs grotter og Sarrautes tropismer, men hos Cunningham er den indre stream-of-consciousness holdt i balance af et fastere ydre sceneri, hvor ting, rum, gestik, miljø og især samspillet med 'den anden' holder tankestrømmen i skak. Cunninghams universer er ikke anonyme eller afpersonaliserede. Tværtimod, sammenstødene mellem de indre uendelige billedstrømme og den foreliggende verdens handlerum, handler om det at være en person.

Laura har svært ved at at være ét med den givne situation, hun har svært ved at identificere sig med den person, som omgivelserne, manden, sønnen, miljøet gør hende til. Hele skildringen af hende pendler mellem de indre flugtmekanismer og forsøgene på at forsone sig med den foreskrevne rolle og gå ind i den:

"Laura stikker hånden i lommen på morgenkåben efter en cigaret, skifter mening, løfter hånden op til håret i stedet.

Det er næsten perfekt, det er næsten nok, at være en ung mor i et gult køkken som rører ved sit kraftige, mørke hår og venter sit andet barn. Der er et mønster af blade på gardinerne; der er frisk kaffe.

Go'morgen, fister, siger hun til Richie. ${ }^{12}$

Den sprække, som 'næsten perfekt' røber, angiver det labile i hendes person:

12. The Hours p. 44, Timerne p. 38. 
»Nå, siger hun da bilen er forsvundet. Hendes søn ser tilbedende på hende, forventningsfuldt. [...]

Nå lad os se, siger hun

Her kommer så den daglige overgang. Når hendes mand er tilstede, er hun mere nervøs, men mindre bange. Hun ved, hvordan hun skal opføre sig. Alene med Richie føler hun det somme tider som om fortøjningerne er kastet - han er så fuldkommen, overbevisende sig selv. Han vil så begærligt det han vil. Han græder gådefuldt, kommer med krav, der er umulige at tyde, bejler til hende, bønfalder hende, ignorerer hende. Det er næsten altid som om han venter og ser hvad hun nu vil gøre. [...] Når hendes mand er her, kan hun klare det. Hun kan se at han ser hende, og hun ved næsten instinktivt hvordan hun skal behandle drengen venligt og bestemt med en kærlig moderlig henkastethed der virker ubesværet. Men når hun er alene med drengen, taber hun tråden. Hun kan ikke altid huske hvordan en mor ville opføre sig. $\star^{13}$

Lauras ønsker om en anden tilværelse er vage og umulige. På den fortalte junidag driver hendes rastløshed hende i to retninger. Ind i læsningen af romanen Mrs. Dalloway, der citeres i længere bidder, og ud i tæt kontakt med selvmordets mulighed. Eller faktisk er det én og samme retning, for bogen får hende bogstaveligt til at flygte fra hverdagen. For et par timer. I stedet for at købe ind til aftenens middag tager hun ind på et hotelværelse i den nærliggende by, hvor hun læser romanen færdig. Og i dette hotelværelse, som både er et ingenmandsland og 'A Room of One’s Own' falder omverdenens definitioner væk, og hun får adgang til en slags møde med sig selv i romanens 'parallelle verden'. Hun deltager i Clarissa Dalloways glitrende følelse af samhørighed med livet på en almindelig sommerdag i London (et sådant intenst øjeblik, som er en grundoplevelse hos Woolf, hendes 'moments of being'). Samtidig identificerer hun sig også med den depressive Woolf og med hendes beslutning om at trække sig ud af det liv, der til sidst syntes for vanskeligt og uoverkommeligt. - Men Cunninghams pointe er jo, at Laura i dette møde med eksistensens ekstremer, eller 'the full range of options', bekræfter livet: at det er båndene til Richie og Dan og til livet overhovedet, der slår igennem og skyder hendes intethedsfølelse i baggrunden. »I could never« er hendes respons, hendes opdagelse.

Der er genklang af Clarissa Dalloways 'moment of being' i Mrs. Brownsekvensens sidste scene, hvor Laura er nået frem til middagen og står foran

13. The Hours p. 47, Timerne p. 40. 
et festdækket spisebord. I ét skrøbeligt øjeblik mødes indre og ydre og samler sig i et hele:

"Spisestuen virker lige nu som den mest perfekt tænkelige spisestue med de jagtgrønne vægge og det mørke ahornsskab der indeholder en samling bryllupssølvtøj. Rummet virker næsten usandsynlig fuldt: fuldt af hendes mands og søns liv; fuldt af fremtiden. Det betyder noget; det skinner. [.....]

Laura aflæser øjeblikket mens det passerer. Her er det, tænker hun; så er det væk. Bladet skal vendes. $\aleph^{14}$

Lauras følelse af endelig at være stillet i fokus, at være tilstede som person, ligger et sted mellem de diskussioner, jeg her har refereret til. Det der skaber hende som person, er langt fra de træk, som skarptegner Balzacs eller Dickens' mindeværdige figurer. Personen Laura Brown står ikke på en piedestal eller troner i en magtposition, snarere bygges Cunninghams person op i en fortløbende diskussion mellem rolle og tilstedeværelse, det er ikke en solist, men en figur, der får sit liv, initiativ og handlerum gennem 'de andre', der definerer personen på godt og ondt og i ustadige skift.

Cunningham har for så vidt de-komponeret den skarptskårne karaktertype, sådan som hele det modernistiske program jo har lagt op til. Men samtidig med at han gør personen mere porøs, genoptager han nogle af de traditionelle rekvisitter, som også Woolf lyste i ban. Miljøbeskrivelsen, køkkenet, stuen, endda bryllupssølvet i det mørke ahornsskab, spiller næsten samme rolle her som i en roman af Balzac, tænk blot på Mme Vauquers pensionat i Père Goriot, hvor møblement og værtinde definerer hinanden, er hinandens symbol. Rummet hos Cunningham er dog ikke symbolsk på den bastante måde. Det er ekspressivt og omskifteligt, det fluktuerer med de forskellige synsvinkler og tilstande hos karaktererne, - samtidig med at inventar og ting over for læseren signalerer dén sociale horisont og ambition, personerne er bundet i. Cunningham har sat personerne tilbage på en synlig social scene. De usynlige sjælelige tunnelgange, som forbinder personerne, og de sociale relationer viser sig hos Cunningham at være to lige vigtige ender af samme indviklede sag.

14. The Hours pp. 207-8, Timerne pp. 163-4. 


\section{Karakteren som erotisk mødepunkt}

Det er selvfølgelig også en klar pointe, at Laura formes som person og karakter gennem sin læsning af Virginia Woolfs roman. Laura læser identificerende og ønskefantaserende, hun oversætter og omsætter mellem sig selv og de fiktive gestalter. Hun søger sin egen kontur i Woolfs personer, og finder også den kontakt, der oplyser et aspekt af hendes liv, sætter det i forgrunden og gør det tydeligt.

Laura Brown er den læser, vi læser. Hun anviser os stedfortrædende vores position som læsere af romanen The Hours - lidt ligesom den rygvendte tilskuer i et landskabsbillede af Caspar David Friedrich fordobler mig, museumsgængeren, der står og kigger på billedet. Laura-figuren åbner dermed for hele den større diskussion om, hvordan den litterære person fungerer som bindeled mellem tekst og læser, og hvad det er for psykiske, semiotiske og kognitive mekanismer, der spilles ud i denne proces. Jeg vil vende tilbage for at sige lidt mere til dette omfattende spørgsmål via en omvej.

I romanens sekvenser om 'Mrs. Dalloway' er der to hovedpersoner, forlæggeren Clarissa Vaughan og hendes ven og ungdomskæreste, forfatteren Richard, som til allersidst viser sig at være identisk med den lille Richie, Lauras søn, altså Richard Brown. Dermed er han den eneste gennemgående figur i bogen, og den eneste, hvis historie vi kender fra vugge til grav. Den aidsramte forfatter når nemlig aldrig frem til prisoverrækkelsen og Clarissas selskab. Han tager den beslutning, som den gale Septimus Smith tog i den rigtige Mrs. Dalloway, han springer ud af vinduet og slår sig ihjel. Dermed er vi tilbage til den intertekstuelle gemmeleg, de tematiske fordoblinger og litterære omfordelinger. Cunningham har nemlig ikke gentaget personlisten ubeskåret som den var i Mrs. Dalloway, hvor Clarissa genser ungdomskæresten Peter Walsh, som hun opgav til fordel for sin mere etablerede ægtemand Richard Dalloway. Cunningham parrer sine 90'er-personer på andre måder. Clarissa har levet et eksperimenterende ungdomsliv i 70'erne i en trekant med Richard (forfatteren) og hans bøsseven som sine to kærester. Men hun har siden opgivet en fremtid med Richard og har stiftet et ægteskabeligt forhold til veninden Sally, som også spiller en rolle i Woolfs roman.

Hvorfor nu al denne kispus med de genbrugte personer? Er der nogen mening i det, eller er det blot uskyldig sporleg? - Jo, der er en mening. Ja ligefrem en tendens.

Jeg har ikke set Cunningham selv svare på spørgsmålet i de interviews, han indtil nu har givet. Men han kunne meget vel svare, at han har transponeret Woolfs personer fra 1920'erne til 1990'erne ved at lade de tendenser, han så i svøb i Woolfs roman, komme til fri udfoldelse under en anden tidsal- 
ders seksualmoral. F.eks.: det magiske kys mellem Clarissa og Sally, som i Mrs. Dalloway forblev en hemmelighed, er i The Hours blevet til et veletableret lesbisk samliv mellem de to, (samtidig med at der også er et ekko af kysset i Laura-historien, kysset mellem Laura og hendes nabo Kitty). Den gale Septimus og den sarkastisk-sentimentale Peter Walsh er i The Hours smeltet sammen i Richard Browns aidssyge forfatterfigur. Clarissas datter Julia (alias Elisabeth) er avlet ved anonym inseminering. $\mathrm{Og}$ så fremdeles.

Bogen handler om den seksuelle frigørelse og dens konsekvenser, det er bogens lavmælte og samlende tema. Dét er også grunden til at Cunningham fastholder blikket på de sociale miljøer og konventioner, og at hans personer ikke skildres isoleret i deres indre monolog eller 'magma', men i den bestandige og urolige dialog mellem impuls og rolle, mellem social forventning og private indre billeder.

Man kan godt kalde bogen en tendensroman. Den vil bringe homoseksualiteten i fokus, - som i den scene, hvor Sally diskuterer med sin filmproducer, om hvorvidt en homoseksuel kærlighedsscene i den film, de arbejder med, vil være en holdbar satsning. Men selv om homoseksualiteten altså er et tema, så er bogens seksualpolitiske budskab mere omfattende og mere subtilt: nemlig dette at seksualiteten ikke er én, men mange ting, at den findes i multiple grader, som en tiltrækning og skabende kraft mellem mennesker, en erotisk kraft, der skaber møder og skæbner. Og også som en kraft, der skaber personer i bøger. Cunninghams intertekstuelle leg med Virginia Woolf, Clarissa Dalloway og Mrs. Brown har dette erotisk skabende moment, tiltrækningen, berøringen, i sig. Det er nemlig det erotiske fokus, der gør persontegningen sensuel, mere fysisk nærværende hos Cunningham end hos modernister som Woolf, Robbe-Grillet og Nathalie Sarraute. Mødet mellem mennesker har hos Cunningham altid en kødelig dimension; tiltrækning, længsel, forståelse, magtspil glider bestandig mellem en sanselig og en intellektuel pol. Og karakteren hos Cunningham er, lige som seksualiteten, ikke én given ting, men en kontinuerlig proces af møder, hvor personerne korrigerer sig selv og hinanden i fysisk-sjælelige vægttilstande. Sommetider er billedet af personen i balance, sommetider rystes og sløres det.

I bogens sekvens om Mrs. Woolf hører vi et eksempel på, hvor let balancen kan skride. I den scene, jeg citerer, har vi fulgt Woolf spadserende gennem Richmond, i dybe tanker om hvordan hun skal udforme figuren Mrs. Dalloway i sin nye roman: 
»Virginia går ind ad døren. Hun føler, at hun fuldstændig styrer den person der er Viginia Woolf, og som den person tager hun sit slag af, hænger det op og går nedenunder for at tale med Nelly om frokosten.

[...] I køkkenet står Nelly og ruller dej ud. Nelly er sig selv, altid sig selv; altid stor og rød, majestætisk, indigneret som om hun havde tilbragt livet i en tidsalder af ære og anstændighed der sluttede for altid, ca. ti minutter før man trådte ind i rummet. Virginia undrer sig over hende. Hvordan kan hun huske, hvordan kan hun klare hver dag og hver time at være nøjagtig den samme? «15

Her opleves mødet med den den anden som anfægtelse og svind af egen autoritet. Andre steder er mødet opdagelse af nye ressourcer. Forholdet mellem Clarissa Vaughan og Richard Brown, der er det mest facetterede i bogen, er eksempel på dette. Deres seksuelle tiltrækning er med tiden blevet til en fysisk ømhed, der bærer over med alder og sygdom, men som stadig forbinder dem i en gensidig interesse. I det følgende citat hører vi Clarissa grunde over deres forhold:

"Richard kan ikke forestille sig et liv der er mere interessant eller rigt end sine bekendtes og sit eget, og af den grund føler man sig ofte opstemt, udfoldet i hans selskab. Han er ikke af den slags egoister, der formindsker andre. Han er den omvendte form for egoist der er drevet af grandiositet snarere end af grådighed, og hvis han insisterer på en udgave af én som er sjovere, underligere, mere exentrisk og dyb end man anede man kunne være - i stand til at gøre mere gavn og mere skade i verden end man nogensinde havde forstillet sig - er det næsten umuligt ikke at tro, i hvertfald i hans selskab og et stykke tid efter man har forladt ham, at han alene ser igennem til ens inderste væsen, afvejer ens sande egenskaber (som ikke allesammen nødvendigvis er smigrende - en vis klodset, barnlig grovhed er en del af hans stil) og værdsætter én i højere grad end nogen andre har gjort det. Det er først når man har kendt ham et stykke tid, at det begynder at gå op for én at man i grunden, for ham, er en fiktiv person, en som han har udstyret med næsten grænseløse evner for tragedie og komedie, ikke fordi det er ens sande natur, men fordi han Richard har brug for at leve i en verden befolket af stærke og ekstreme skikkelser. Nogle har afsluttet deres forhold til ham fremfor at fortsætte som figurer i det episke digt han altid skriver på i hovedet, historien om sit liv og sine lidenskaber; men andre (heriblandt Clarissa) nyder den følelse af overdrivelse han tilfører deres liv, er blevet afhængige af den ligesom de er

15. The Hours p. 84, Timerne p. 69. 
afhængige af at kaffe skal vække dem om morgenen, og en drink eller to skal få dem til at gå omkuld om aftenen. $\star^{16}$

Vinklen er Clarissas, hun akcepterer illusionen som en del af deres sandhed, men måske ser hun ikke dynamikken mellem dem hele vejen rundt. Cunningham lader os i hvertfald ane, at Richards tragik, og hans selvmord til sidst, også har noget at gøre med en kontakt, som hun har nægtet ham på et dybere plan.

Hver enkelt person hos Cunningham er et netværk af impressioner og stemmer, som forbinder sig med de andre personer i vekslende dialoger, tiltrækninger og ansvar. Bogens intertekstuelle komposition er den indlysende demonstration af dette væv, dette interpersonelle bevægelige væv af sandhed og fiktion og bindinger. Personen, karakteren bliver hele tiden til i en fortløbende afprøvning af nye betydninger, og i forsøget på at finde balancepunkter undervejs i processen. Vi ser skredene og usikkerheden hos Virginia, Laura og Clarissa i løbet af de timer vi følger deres liv, og vi ser hvordan de, op mod tiden, timerne, søger at vinde stabiliserende overblik. Hos Virginia og Laura vindes balancen gennem en særlig form for tilbagetrækning og distance, de træder begge på opmærksom afstand af sig selv i deres eksperimenterende indlevelse $\mathrm{i}$ den samme fiktive gestalt, nemlig i hovedpersonen Clarissa Dalloway i den roman Virginia Woolf skriver i 1924 og som Laura Brown er i færd med at læse 25 år senere.

\section{Distance og indlevelse}

Opmærksom distance og eksperimenterende indlevelse er måske også den formel Cunningham skriver sine personer på i The Hours og den læsemodus vi læser dem i. Distancen er givet med personernes gennemsigtighed, deres konstruerethed oven på de litterære forlæg. Mens indlevelsen, ja jeg vil ligefrem sige den sanselige kontakt med personernes verden, ligger på et andet plan. I sproget, i tekstens metaforiske lag, der skaber forbindelser på tværs og gør flygtige sanse- og grænsetilstande tilgængelige for læseren. Cunningham åbner sproglige tunnelgange mellem sine personer og kobler også læseren til via dette relæ-system i teksten. Men fordi læseridentifikationen således kobler til og fra efter et multipelt system af forbindelser, stilles læseren også fri af teksten. Jeg opsluges ikke i mimetisk indlevelse, som når jeg læser en klassisk realistisk fortælling, hvor handling, psykologi og syns-

16. The Hours pp. 60-61, Timerne p. 51. 
vinkel driver mig gennem teksten i et afhængighedsforhold til den dominerende hovedperson. Derfor oplever jeg heller ikke ved endt læsning af The Hours den velkendte læsertristesse, når bogen er lukket, og 'mine' personer trækker sig tilbage til deres eksklusive egetliv og lader mig ene og fortabt tilbage. Tværtimod, giver personfletværket i The Hours mig plads til at stige med på interteksten og til at fortsætte dialogen ud over bogens egen, for anledningen, temporært opsatte platform. 